\title{
Correction to: Driving status and health-related quality of life among the oldest old: a population-based examination using data from the AgeCoDe-AgeQualiDe prospective cohort study
}

\author{
André Hajek ${ }^{1}$. $\cdot$ Christian Brettschneider ${ }^{1} \cdot$ Dagmar Lühmann $^{2} \cdot$ Hendrik van den Bussche $^{2} \cdot$ Birgitt Wiese $^{3}$. \\ Silke Mamone ${ }^{3}$. Siegfried Weyerer ${ }^{4}$. Jochen Werle ${ }^{4} \cdot$ Verena Leve $^{5} \cdot$ Angela Fuchs $^{5}$. Susanne Röhr ${ }^{6}$. Janine Stein ${ }^{6}$. \\ Horst Bickel $^{7} \cdot$ Edelgard Mösch $^{7} \cdot$ Kathrin Heser ${ }^{8} \cdot$ Michael Wagner $^{8,9} \cdot$ Martin Scherer $^{2} \cdot$ Wolfgang Maier $^{8,9}$. \\ Steffi G. Riedel-Heller ${ }^{6} \cdot$ Michael Pentzek $^{5} \cdot$ Hans-Helmut König ${ }^{1}$
}

Accepted: 23 June 2021 / Published online: 5 July 2021

(c) The Author(s) 2021

\section{Correction to: Aging Clinical and Experimental Research https://doi.org/10.1007/s40520-020-01482-7}

The article Driving status and health related quality of life among the oldest old: a population based examination using data from the AgeCoDe-AgeQualiDe prospective cohort study, written by André Hajek, Christian Brettschneider, Dagmar Lühmann, Hendrik van den Bussche, Birgitt Wiese, Silke Mamone, Siegfried Weyerer, Jochen Werle, Verena Leve, Angela Fuchs, Susanne Röhr, Janine Stein, Horst Bickel, Edelgard Mösch, Kathrin Heser, Michael Wagner, Martin Scherer, Wolfgang Maier, Steffi G. Riedel-Heller, Michael Pentzek and Hans-Helmut König was originally published electronically on the publisher's internet portal (currently SpringerLink) on 11 rd January 2021 without open access. With the author(s)' decision to opt for open choice, the copyright of the article changed on 1st July 2021 to (C) The Author(s) 2021 and the article is forthwith distributed under the terms of the Creative Commons Attribution 4.0 International License (http://creativecommons.org/licen ses/by/4.0/), which permits use, duplication, adaptation, distribution and reproduction in any medium or format, as long as you give appropriate credit to the original author(s) and the source, provide a link to the Creative Commons license and indicate whether changes were made.

The original article has been corrected.

The original article can be found online at https://doi.org/10.1007/ s40520-020-01482-7.

André Hajek

a.hajek@uke.de

1 Department of Health Economics and Health Services Research, Hamburg Center for Health Economics, University Medical Center Hamburg-Eppendorf, Hamburg, Germany

2 Department of Primary Medical Care, Center for Psychosocial Medicine, University Medical Center Hamburg-Eppendorf, Hamburg, Germany

3 Institute of General Practice, Hannover Medical School, Hannover, Germany

4 Medical Faculty Mannheim, Central Institute of Mental Health, Heidelberg University, Mannheim, Germany
5 Institute of General Practice, Medical Faculty, Heinrich-Heine-University Düsseldorf, Düsseldorf, Germany

6 Institute of Social Medicine, Occupational Health and Public Health, University of Leipzig, Leipzig, Germany

7 Department of Psychiatry, Technical University of Munich, Munich, Germany

8 Department of Neurodegenerative Diseases and Geriatric Psychiatry, University of Bonn, Bonn, Germany

9 German Center for Neurodegenerative Diseases (DZNE), Bonn, Germany 
Open Access This article is licensed under a Creative Commons Attribution 4.0 International License, which permits use, sharing, adaptation, distribution and reproduction in any medium or format, as long as you give appropriate credit to the original author(s) and the source, provide a link to the Creative Commons licence, and indicate if changes were made. The images or other third party material in this article are included in the article's Creative Commons licence, unless indicated otherwise in a credit line to the material. If material is not included in the article's Creative Commons licence and your intended use is not permitted by statutory regulation or exceeds the permitted use, you will need to obtain permission directly from the copyright holder. To view a copy of this licence, visit http://creativecommons.org/licenses/by/4.0/.

Publisher's Note Springer Nature remains neutral with regard to jurisdictional claims in published maps and institutional affiliations. 